Int. J. Morphol.,

32(2):614-617, 2014.

\title{
Study of Wistar Rats Heart at Different Stages in the Evolutionary Cycle
}

\author{
Estudio del Corazón de Ratas Wistar en Diferentes Etapas del Ciclo Evolutivo
}

\author{
De Carvalho, C. A. M.* \& Thomazini, J. A.**
}

\begin{abstract}
DE CARVALHO, C. A. M. \& THOMAZINI, J. A. Study of Wistar rats heart at different stages in the evolutionary cycle. Int. J. Morphol., 32(2):614-617, 2014.

SUMMARY: The rat is probably the most commonly used animal in scientific research. There are many benefits to its use such as: ability to work a large number of animals allowing greater statistical validity, the relatively short life cycles. However, the scant literature regarding the anatomy and morphology of these animals is also old and not very descriptive. The objective of this research is to study the macroscopic morphometric aspects of several parameters that have not been described yet regarding the heart of Wistar rats in different phases of their lives. Thirty-six adult male and female rats (Rattus norvegicus) weighting 150-770 g were randomly divided into 6 experimental groups. The heart was then carefully dissected and removed from the chest. After this process, the heart had their weight measured on a precision scale HELMAC HM100, and for each front section of the heart related measures were taken through a semi-automatic image analysis of Kontron Build Analyse (Minimop). The percentage ratio between the relative heart weight to body weight was between 0.5 and $0.7 \%$ in the animals with body weight up to $650 \mathrm{~g}$. The maximum and minimum diameters were always statistically lower in females compared to males. The measurements showed the hearts of the females shorter, narrower, smaller and lighter than those of males. Over the life of these females, although the heart weight increases, the heart apparently keeps its shape and size. Furthermore, the hearts of males narrow and stretch along their development.
\end{abstract}

KEY WORDS: Weight; Measures; Heart; Rats.

\section{INTRODUCTION}

The biomaterial's easy manipulation, the ability to work a large number of animals allowing greater statistical validity, the relatively short life cycles, the high rate of reproduction, are unquestionable factors for the maintenance of these animals on the list of the most used in science. But there are also some restrictions such as the inability to collect large amount of material due to animal size, for example, the phylogenetic distance of man and the fact that they live in totally artificial environment (Ribeiro et al., 1995).

Addition to the constraints above, the literature about the anatomy of these animals is scarce and description is limited, especially when the demand is for information about the anatomy of the rat's heart. Schneider (1938) described that mouse lacks brachiocephalic veins. The external jugular vein of rats is of relatively larger caliber, compared with the internal jugular and drain portions of the head and neck. After crossing the first ribs, the external jugular veins empty into the subclavian veins along with the corresponding internal jugular veins on each side. Two vena cava (upper) are formed entering the right atrium separately.

Some early articles describe the specific anatomy of the rat. One, for example, 300 describes some parameters in rat species not reported. The work does not detail how the hearts were dissected especially in relation to vessels and has three results: 0.289 percent as the ratio between heart weight and body weight of animal, 0345 when the fat is removed around the heart and 0238 , when removal of the fat addition, the heart is dried (Caster et al., 1956).

The heart of the males has much higher absolute weight compared with the absolute heart weight of females in normal adult albino rats. This weight in males is approximately $0.9 \mathrm{~g}$ to animals $200-300$ grams body weight. For males weighing over 450 grams, the weight of the heart can reach up to 1 gram. In females, the range is from $0.67 \mathrm{~g}$ to animals between $170-200 \mathrm{~g}$ body weight, up to $0.8 \mathrm{~g}$ ani-

\footnotetext{
* Postgraduate Student-Doctorate, Department of Surgery and Anatomy, Ribeirão Preto Faculty of Medicine, University of São Paulo (USP), Ribeirão Preto, Brazil. ${ }^{* *} \mathrm{PhD}$, Doctor Professor-Department of Surgery and Anatomy, Ribeirão Preto Faculty of Medicine, University of São Paulo (USP), Ribeirão Preto, Brazil.
} 
mal body weight above 280 grams. When these values are divided by the animals' body weight, the difference between sexes is reduced. The weight of the ventricles, both right and left, the study demonstrates approximately the same relationship (Krames \& Van Liere, 1966). The weight of the whole heart of rats, been established corrected for body weight, a value of $2.98 \pm 0.15 \mathrm{mg} / \mathrm{g}$ body weight, with $\mathrm{p}$ $<0.05$ in 16 animals with body weight $180-220$ grams. Nor does it describe in detail the methodology for obtaining these hearts (Medeiros et al., 2000). Medeiros et al. (2004) described the ratio of heart weight / body weight in 12 male albino Wistar, weighing 200-220 $\mathrm{g}$ and $2.82 \pm 0.16 \mathrm{mg} / \mathrm{g}$, where the hearts were removed and the dissection of the thoracic cavity was described only as obtaining hearts after removal of non-cardiac tissues. Therefore, this article proposes to make a detailed study of the heart weight of these animals in relation to body weight than the minimum and maximum diameters of the body so that future researchers can obtain more detailed information.

\section{MATERIAL AND METHOD}

Thirty-six adult male and female rats (Rattus norvegicus) weighting $150-770 \mathrm{~g}$ were used. The animals were randomly divided into 6 experimental groups: 6 animals of the group I male-weighting 150-249 g (I-M); 6 animals of the group I female-weighting 150-249g (I-F); 6 animals of the group II male-weighting 250-350g (II-M); 6 animals of the group II-female-weighting (II-F); 6 animals of the group III-male weighting more than $351 \mathrm{~g}$ (III-M); 6 animals of the group III-female weighting more than $351 \mathrm{~g}$ (III-F). The study was approved by the Animal Experimentation Committee (CETEA) of the Faculty of Medicine of Ribeirão Preto, University of São Paulo (Protocol no 0347/2005). The experiments were carried out according to the Ethical Principles for Experimental Animals (COBAO).

Once anesthetized, the animals were placed on the surgical table for bilateral thoracotomy. The heart was removed and dissected using a standardized method. Were weighed using precision scales HELMAC HM100. After heavy, hearts were subjected to routine histologic technique for paraffin embedding and staining with hematoxylin-eosin (H\&E). After inclusion in paraffin, the resulting blocks were cut into $10 \mathrm{~mm}$ thick with microtome R JUNG AG HEIDELBERG (Fig. 1). The maximum diameter (Dmax) and the minimum diameter (Dmin) of the blades hearts were measured through a semi-automatic image analysis of the Build Kontron Analyse (Minimop). Dmax was measured from the point most caudal (inferior) of the interventricular septum of the heart to the point more rostral (superior) of

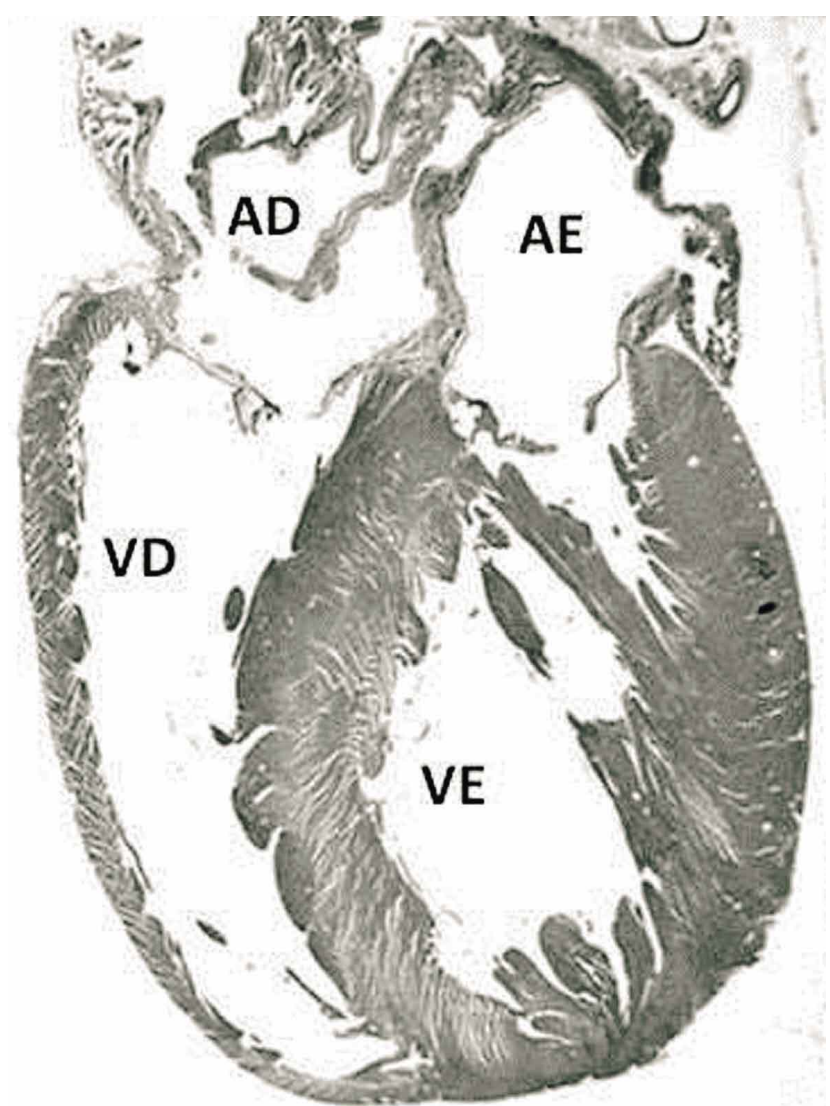

Fig. 1. Macrophotography of the frontal cut of the heart of albino Wistar rats (10 $\mu \mathrm{m}$ of thickness). Coloring: HE. Enlargement: 3.7X.

the atrial septum. The Dmin was measured by a straight line at the time of the valves atrioventriulares corresponding to the atrioventricular groove.

The data concerning the mean of the morphometric and anatomical analysis in the various groups were statistically analyzed by ANOVA using the PROC GLM SAS, version 9 for Windows. The level of significance was set at $\mathrm{p}<0.05$ for two-tailed tests. For determining the linear correlation coefficient, it was suggested the Pearson correlation coefficient, denoted by r (Pagano \& Gauvreau, 2004).

\section{RESULTS AND DISCUSSION}

The body weight ranged from 150-770 $\mathrm{g}$ with an average of $343.47 \mathrm{~g}$ for the three groups. Heart weight ranged from 1.100 to 3.456 grams. The weight average heart dissected from all animals of the sample was 2.006 grams. Intra-group significant difference between males and females in groups II and III ( $\mathrm{p}<0.05)$. In intergroup comparison, for 
both males and females were observed statistically significant differences between groups I and III, and between group II and group III. The relationship between the heart and body weight are shown in Figure 2. The Pearson correlation coefficient is 0.854 .

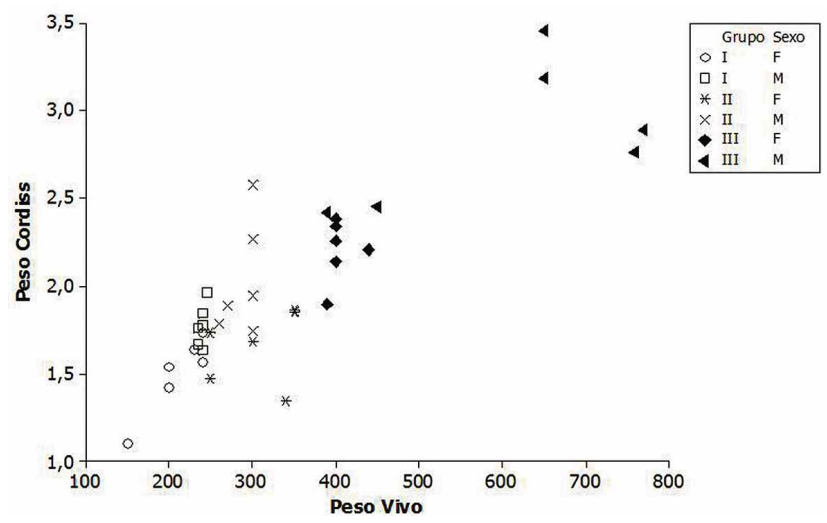

Fig. 2. Dispersion of the weight of live animals vs. weight of the dissected heard according to the group in both sexes. (Correlation coefficient: $r=0,854$; $p$ value $<0,01)$.

The ratio of weights of the relative heart weight to body organs showed that they represent mean values between approximately 0.5 and $0.7 \%$ by weight of animals to those with body weight to $650 \mathrm{~g}$. From this weight, this ratio decreases, and stabilized even tends to be decreased along aging, since the animals continued to gain weight, no corresponding increase in size and weight of the heart.

The Dmax statistical significance in groups I and III in the intragroup comparison. As for males, significant difference in the comparison between groups I and III and between groups II and III. The Dmin within the groups showed statistically significant difference for groups I and III. Group II presented estimate of 0.03 in favor of males (Fig. 3A and 3B).

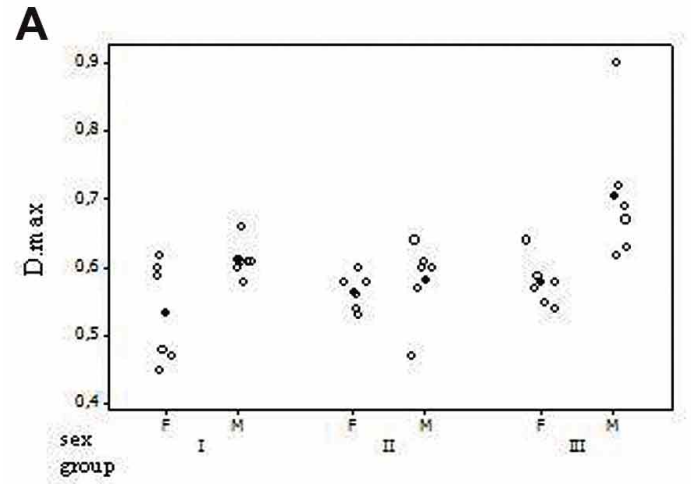

Both the minimum and maximum diameter were significantly lower for females in groups I and III to group II, although statistical equality, this parameter was also in absolute value, lower for females. These data suggest the existence of sexual dimorphism, where the hearts of the females used in this experiment are shorter, narrower, smaller and lighter than those of males.

The lack of statistical difference between groups was significant in females and may indicate that over the life of these females, although the heart weight increases the heart apparently keeps its shape and size. Among males, there is only statistical difference for the maximum diameter in the comparisons between groups I and III and between II and III to increase this value. The minimum diameter, although not statistically significant, tends to suffer a decrease in their average values, suggesting that the hearts of male animals are stretching and narrowing along its development.

DE CARVALHO, C. A. M. \& THOMAZINI, J. A. Estudio del corazón de ratas Wistar en diferentes etapas del ciclo evolutivo. Int. J. Morphol., 32(2):614-617, 2014.

RESUMEN: La rata es probablemente el animal más utilizado en investigaciones científicas. Hay muchos beneficios por su uso como la capacidad de trabajar con un gran número de animales permitiendo una mayor validez del punto de vista estadístico o el ciclo de vida relativamente corto del animal. Sin embargo, la escasa literatura sobre la anatomía y la morfología de la rata es antigua y no muy descriptiva. El objetivo de esta investigación fue estudiar parámetros morfométricos macroscópico no descritos con respecto al corazón de la rata Wistar en diferentes fases de la vida. Treinta y seis ratas (Rattus norvegicus) adultas, hembras y machos pesando entre 150-770 g, fueron divididas al azar en 6 grupos diferentes. El corazón fue cuidadosamente disecado y retirado del tórax. Cada corazón fue pesado en una balanza de precisión y para cada sección frontal del corazón fueron tomadas medidas relativas mediante un análisis de imágen semi-automático Kontron

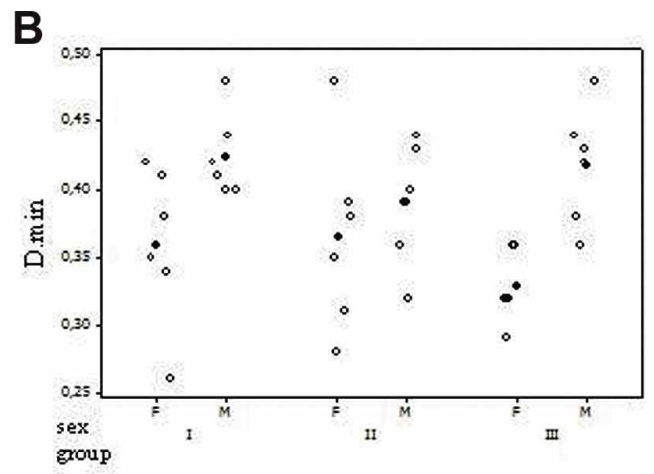

Fig. 3 A and 3B- Dispersion of the Dmax (A) and Dmin (B) variables in the different groups and sex. The full dots represent the average of the values. 
Build Analyse (Minimop). El porcentaje de proporción entre el peso relativo del corazón y el peso del cuerpo fue entre $0,5-0,7 \%$ en animales con peso corporal de hasta $650 \mathrm{~g}$. Los diámetros máximos y mínimos fueron estadísticamente menores en hembras comparádolos con machos. Las medidas mostraron que los corazones en las hembras son más cortos, angostos, pequeños y livianos que en machos. Durante la vida de estas hembras, aunque el peso del corazón aumenta, aparentemente mantiene su forma y su tamaño. Por otro lado, los corazones de los machos se estiran y se estrechan durante su desarrollo.

\section{PALABRAS CLAVE: Peso; Medidas; Corazón; Ratas.} weights of the rat. I. Normal values determined by dissection and chemical methods. Proc. Soc. Exp. Biol. Med., 91(1):122$6,1956$.

Harkness, J. E. \& Wagner, J. E. Biologia e Clínica de coelhos e roedores. $3^{\text {a }}$ ed. São Paulo, Editora Roca, 1993.

Krames, B. B. \& Van Liere E. J. The heart weight and ventricular weights of normal adult albino rats. Anat. Rec., 156(4):461-4, 1966.

Medeiros, A.; Gianolla, R.; Kalil, L. M. P.; Bacurau, R. F. P.; Rosa, L. F. B. C.; Negrão, C. E. \& Brum, P. Efeito do treinamento físico de natação sobre o sistema cardiovascular de ratos normotensos. Rev. Paul. Educ. Fis., 14(1):7-15, 2000.

Medeiros, A.; Oliveira, E. M.; Gianolla, R.; Casarini, D. E.; Negrão C. E. \& Brum, P. C. Swimming training increases cardiac vagal activity and induces cardiac hypertrophy in rats. Braz. J. Med. Biol. Res., 37(12):1909-17, 2004.

Pagano, M. \& Gauvreau, K. Princípios de Bioestatística. São Paulo, Editora Thomson, 2004.

Ribeiro, S. M. L.; Campos, P. \& Tirapegui, J. O rato como animal de laboratório: histórico, dados biológicos e análise crítica de seu uso. Rev. Farm. Bioquím. Univ. São Paulo, 31(1):21-8, 1995.

Schneider, L. A. The development of the superior caval system in the rat. Anat. Rec., 71(3):265-76, 1938.

\author{
Correspondence to: \\ Camila Albuquerque Melo de Carvalho \\ Department of Surgery and Anatomy \\ Ribeirão Preto Faculty of Medicine \\ University of São Paulo (USP) \\ Avenida Bandeirantes 3900, 14049-900 \\ Ribeirão Preto, SP \\ BRAZIL \\ Email: camilaamc@yahoo.com.br
}

Received: 14-12-2013

Accepted: 31-03-2014 